\title{
The Mitigation of Alkali-Silica Reactions by Aluminum-Bearing Substances
}

\author{
Alexey Brykov, Anna Anisimova, Natalia Rozenkova \\ Department of Chemistry of Substances and Materials, St. Petersburg State Institute of Technology, \\ St. Petersburg, Russia \\ Email: brykov@yahoo.com
}

Received 8 March 2014; revised 11 April 2014; accepted 23 April 2014

Copyright (C) 2014 by authors and Scientific Research Publishing Inc.

This work is licensed under the Creative Commons Attribution International License (CC BY). http://creativecommons.org/licenses/by/4.0/

(c) (i) Open Access

\section{Abstract}

An ability of aluminum-bearing substances-amorphous aluminum hydroxide, aluminum sulphate and basic aluminum sulphate to mitigate alkali-silica reactions in Portland cement mortars has been studied. At equivalent dosages in terms of $\mathrm{Al}_{2} \mathrm{O}_{3}$, these substances are ranged in the following order in respect of inhibiting effect: $\mathrm{Al}(\mathrm{OH})_{1.78}\left(\mathrm{SO}_{4}\right)_{0.61} \geq \mathrm{Al}_{2}\left(\mathrm{SO}_{4}\right)_{3}>\mathrm{Al}(\mathrm{OH})_{3}$. It is found that the plasticizing agents of the main types used in cement compositions have no influence on the inhibiting effect of aluminum-bearing admixtures. To control the setting time of cement paste, iron(II) sulphate may be used for partial substitution of $\mathrm{Al}_{2} \mathrm{SO}_{4} \cdot 18 \mathrm{H}_{2} \mathrm{O}$, and this operation is not influence on the results of ASR expansion test.

\section{Keywords}

Alkali-Silica Reaction Mitigation, Aluminum Hydroxide, Aluminum Sulphate, Basic Aluminum Sulphate, Concrete, Iron(II) Sulphate, Portland Cement, Superplasticizers, Water-Reducing Admixtures

\section{Introduction}

The presence of reactive $\mathrm{SiO}_{2}$-inclusions in fine and coarse aggregates is one of the factors that negatively affect the durability of concrete. The interaction of reactive $\mathrm{SiO}_{2}$ with alkalis coming into pore fluid from outside or from the concrete mix components leads to the formation of the products causing significant internal tense stressses and destructive deformations of concrete [1].

The widely used way to prevent alkali-silica reactions (ASR) is the introducing of pozzolanic additives-silica fume, metakaolin, fly-ash, ground granulated blast furnace slag — into concrete mix [2] [3]. These additives exhibit efficacy as inhibitors of ASR at dosages of $15 \%-50 \%$ by weight of cement. Nevertheless, the substitution 
of significant part of fine aggregate or cement in the concrete mix by pozzolanic additives has not always a positive effect on the main properties of mortars and concretes: w/c ratio, consistency, workability, strength.

Some chemical compounds have high effectiveness in mitigation of ASR; among them, lithium compounds are studied to the fullest extent [4]. The effect of lithium ions is due to the passivation of reactive $\mathrm{SiO}_{2}$-inclusions with slow soluble lithium silicates. In comparison with pozzolanic additives, lithium-bearing admixtures are effective at low dosages. The research and application of lithium substances as ASR inhibitors are practiced mainly in USA due to sufficient lithium reserves in the form of hydro-mineral brines [5].

Therefore, the searching for perspective ASR inhibitors should be focused on the materials and chemical compounds which are easier to access in comparison with lithium salts, and also more efficient than pozzolanic additives. In this regard, using aluminum-bearing substances seems promising. It was found that pre-treatment of reactive silica with aluminum sulphate decreases its dissolution in $\mathrm{NaOH}$ solutions [6]. The ability of amorphous and crystalline aluminum hydroxides to inhibit expansion of Portland cement mortars with reactive aggregates in alkaline solutions was demonstrated in [7]. The authors of [7] have proposed that high inhibition activity of amorphous forms of $\mathrm{Al}(\mathrm{OH})_{3}$ (as compared to crystalline modifications) is concerned with their ability to bind $\mathrm{Ca}(\mathrm{OH})_{2}$.

At present, aluminum-bearing substances-amorphous $\mathrm{Al}(\mathrm{OH})_{3}$, aluminum sulphate and basic aluminum sulphate are used as alkali-free set and hardening accelerators for Portland cement concretes, especially in shotcrete technology [8] [9]. Therefore, there is a practical interest to carry out a comparative study of amorphous $\mathrm{Al}(\mathrm{OH})_{3}$, aqueous solutions of aluminum sulphate and basic aluminum sulphate as inhibitors of ASR in Portland cement mortars containing reactive aggregates.

\section{Experimental Part}

\subsection{Materials}

Highly dispersed amorphous aluminum hydroxide Geloxal 10 ("Industrias Químicas del Ebro", Spain) with LOI $47.3 \mathrm{wt} \%$ (at $900^{\circ} \mathrm{C}$ ), specific surface area of $17.8 \mathrm{~m}^{2} / \mathrm{g}$, particle size up to $20 \mu \mathrm{m}$, and aluminum sulphate $\mathrm{Al}_{2}\left(\mathrm{SO}_{4}\right)_{3} \cdot 18 \mathrm{H}_{2} \mathrm{O}$ (ALG, "Kemira Oyj", $\mathrm{Al}_{2} \mathrm{O}_{3} 17.0 \mathrm{wt} \%$ ) were used as aluminum-bearing admixtures. The same substances were also used in preparing aqueous solution of basic aluminum sulphate $\mathrm{Al}(\mathrm{OH})_{1.78}\left(\mathrm{SO}_{4}\right)_{0.61}(15.1 \%$ based on $\mathrm{Al}_{2} \mathrm{O}_{3}$ ). The synthesis of composition was done in accordance with [10]. Before being taken into use, the solution was stored for 1 day after preparation.

Portland cement CEM I $42.5 \mathrm{~N}$ with the following composition, wt\%: $\mathrm{C}_{3} \mathrm{~S} 52-53, \mathrm{C}_{2} \mathrm{~S} 18-20, \mathrm{C}_{3} \mathrm{~A}+\mathrm{C}_{4} \mathrm{AF}$ 20 - 22, gypsum $\left(\mathrm{CaSO}_{4} \cdot 2 \mathrm{H}_{2} \mathrm{O}\right) 3-4$, anhydrite $\left(\mathrm{CaSO}_{4}\right) 1, \mathrm{CaCO}_{3} 2$ was used.

As aggregate, a quartz-feldspar sand of the following fractional composition, wt $\%$, was used: $1.25-2.5 \mathrm{~mm}$ $-5.27,0.63-1.25 \mathrm{~mm}-27.5 ; 0.315-0.63 \mathrm{~mm}-27.5 ; 0.16-0.315 \mathrm{~mm}-17.5$. In the initial aggregate, the content of $\mathrm{SiO}_{2}$ dissolvable in $\mathrm{NaOH}$ was determined in accordance to methods described in GOST 8269.0 - 97 specification and is found to be equal to 0 , means an aggregate material is not reactive in alkali environment. Sand was ignited in a muffle furnace in the following manner: $2.5 \mathrm{hrs}$ at $1000^{\circ} \mathrm{C}+2.5 \mathrm{hrs}$ at $1080^{\circ} \mathrm{C}$ (until the sintering is slightly produced) followed by a rapid cooling to ambient temperature. The total duration of heat treatment was $8.5 \mathrm{hrs}$ including periods of the temperature rising. After cooling, the material was crashed in porcelain jar to disintegrate large cakes formed during sintering and after that was graded.

In accordance with petrography data, in all fractions of fired sand there is a glassy phase in amount of 3 to $12 \%$; the surface of some part of quartz grains $(3 \%-7 \%)$ is covered by secondary needlelike new growths; feldspar grains are strongly modified. The soluble $\mathrm{SiO}_{2}$ content in fired sand has reached $57 \mathrm{mmol} / \mathrm{l}$.

\subsection{Testing Methods}

The alkali-silica expansion of cement-sand mortars with the addition of aluminum-bearing admixtures and reference samples (without admixtures) was investigated by the accelerated test in accordance with GOST 8269.0 specification (analog to mortar-bar test method ASTM C 1260).

A reference mortar mix was prepared by mixing sand with cement at a ratio of 2.25:1 (by weight), water-to-cement ratio was 0.4 . Mixtures with aluminum-bearing admixtures in amount of $0.5 \%$ and $1 \%$ in terms of equivalent dosage of $\mathrm{Al}_{2} \mathrm{O}_{3}$ of cement weight were similarly prepared (w/c 0.4$)$. Aluminum hydroxide was previously mixed with dry components. Aluminum sulphate hydrate and the solution of basic aluminum sulfate 
were added to cement-sand mix with mixing water. The water content in aluminum sulphate and basic aluminum sulphate was taken into account.

Mortar mixes were put into molds $(20 \times 20 \times 100) \mathrm{mm}$. In accordance with the procedure, after 1 day of storage at $100 \% \mathrm{RH}$ and $20^{\circ} \mathrm{C}$ samples were demolded and put into water at $80^{\circ} \mathrm{C}$ for one day. Samples were then cooled in a sealed box to $20^{\circ} \mathrm{C}$ and samples' lengths were measured. During the test period, samples have being stored in $1 \mathrm{M} \mathrm{NaOH}$ at $80^{\circ} \mathrm{C}$, daily measurements of samples length were performed (total test duration was 2 weeks). For each mix two sample bars were made, an average elongation of two samples is taken as a measurement result.

\section{Results and Discussion}

Figure 1 shows the dependence of the expansion of mortar samples stored in the conditions of an accelerated test procedure on time. From these data it follows that to the end of test (14 days), an expansion of control mortar sample is about $0.23 \%$, i.e. - this is higher than the threshold value $(0.1 \%)$, which is the criteria for characterizing the aggregate as a reactive or non-reactive to alkalis.
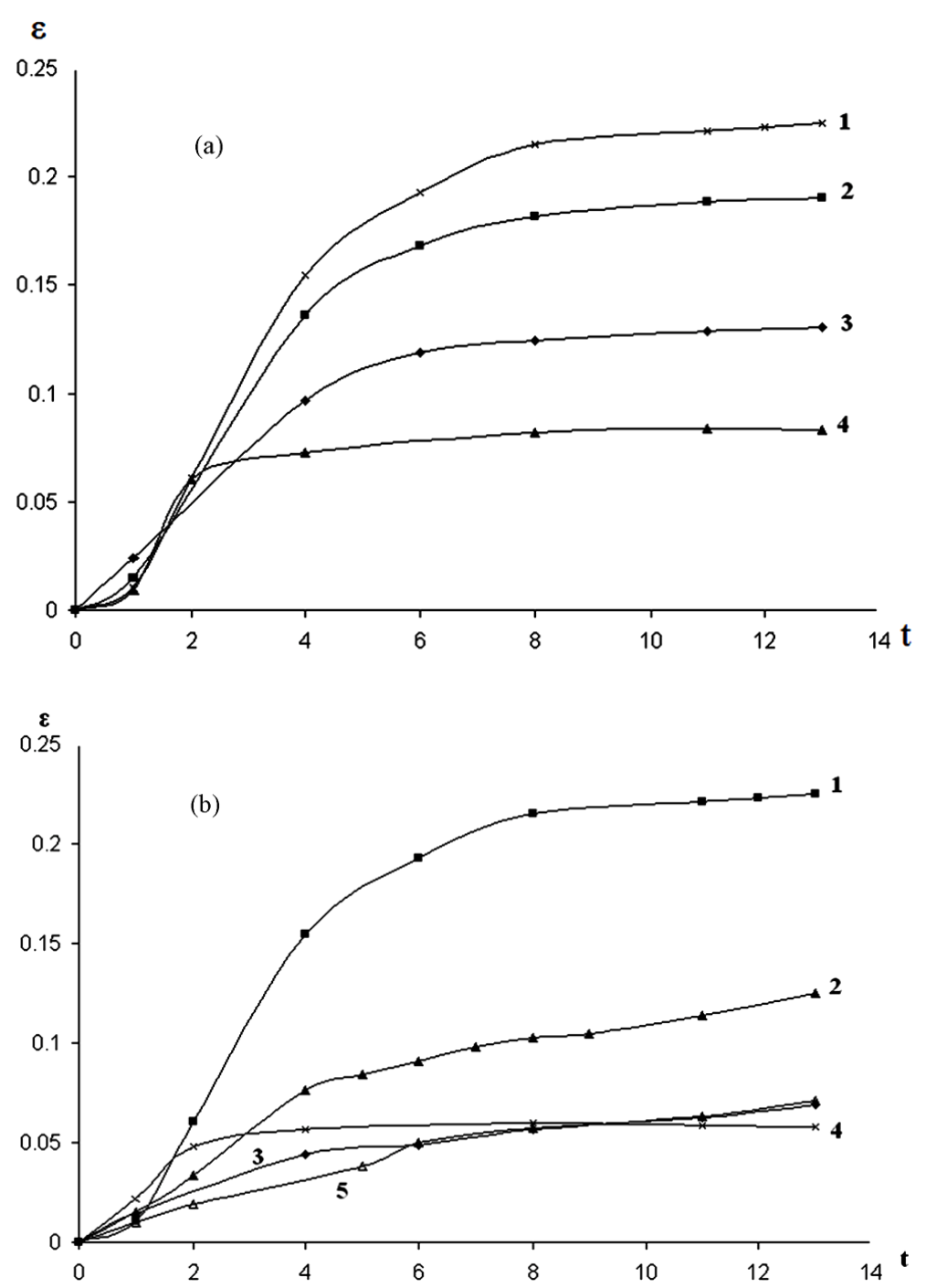

Figure 1. Linear expansion $\varepsilon(\%)$ of samples with aluminum-bearing admixtures $\left(1-\right.$ reference sample, $2-\mathrm{Al}(\mathrm{OH})_{3}, 3-\mathrm{Al}_{2}\left(\mathrm{SO}_{4}\right)_{3}, 4-\mathrm{Al}(\mathrm{OH})_{1.78}\left(\mathrm{SO}_{4}\right)_{0.61}$, $\left.5-\mathrm{Al}_{2}\left(\mathrm{SO}_{4}\right)_{3}+\mathrm{FeSO}_{4}\right)$ stored in $1 \mathrm{M} \mathrm{NaOH}$ versus time (days) at dosages in terms of $\mathrm{Al}_{2} \mathrm{O}_{3}, \%$ of the weight of cement: $\mathrm{a}-0.5 ; \mathrm{b}-1$. 
As it may be seen on Figure 1, all aluminum-containing compounds exhibit the ability to suppress destructive processes with the participation of reactive aggregates. Differences in the effectiveness of additives come in full force at small dosage (see Figure 1(a)). Basic aluminum sulphate possesses more inhibiting effect in comparison with aluminum sulphate at dosage $0.5 \%$ (in terms of $\mathrm{Al}_{2} \mathrm{O}_{3}$ ) of the weight of cement (Figure 1(a)). The increasing of dosages of aluminum bearing substances up to $1 \%$ (in terms of equivalent amount of $\mathrm{Al}_{2} \mathrm{O}_{3}$ ) leads to increased inhibitory effect, while neglecting any difference in admixtures' efficacy. Aluminum hydroxide is the least effective both, at low and increased dosages.

During the earliest period of hydration, the substances $\mathrm{Al}(\mathrm{OH})_{1.78}\left(\mathrm{SO}_{4}\right)_{0.61}, \mathrm{Al}_{2}\left(\mathrm{SO}_{4}\right)_{3}$ and $\mathrm{Al}(\mathrm{OH})_{3}$ are characterized by the high activity in cement paste which consists in binding of gypsum and $\mathrm{Ca}(\mathrm{OH})_{2}$ with formation of ettringite [8] [10]:

$$
\begin{gathered}
\mathrm{Al}_{2}\left(\mathrm{SO}_{4}\right)_{3}+6 \mathrm{Ca}(\mathrm{OH})_{2}+26 \mathrm{H}_{2} \mathrm{O} \rightarrow 3 \mathrm{CaO} \cdot \mathrm{Al}_{2} \mathrm{O}_{3} \cdot 3 \mathrm{CaSO}_{4} \cdot 32 \mathrm{H}_{2} \mathrm{O} \\
2 \mathrm{Al}(\mathrm{OH})_{3}+3 \mathrm{Ca}(\mathrm{OH})_{2}+3\left(\mathrm{CaSO}_{4} \cdot 2 \mathrm{H}_{2} \mathrm{O}\right)+20 \mathrm{H}_{2} \mathrm{O} \rightarrow 3 \mathrm{CaO} \cdot \mathrm{Al}_{2} \mathrm{O}_{3} \cdot 3 \mathrm{CaSO}_{4} \cdot 32 \mathrm{H}_{2} \mathrm{O}
\end{gathered}
$$

Apparently, this can explain the ability of all three compounds to inhibit alkali - silica reactions in Portland cement compositions with reactive aggregates. As is known, $\mathrm{Ca}(\mathrm{OH})_{2}$ produced by hydration of silicate phases of Portland cement is involved in destructive alkali - silica reactions and contributes to the destructive expansion processes [11] [12].

Comparative study of the influence of basic aluminum sulphate and aluminum hydroxide on the hydration of Portland cement has shown that in the initial period of hydration more ettringite forms in case of basic aluminum sulphate than in case of amorphous $\mathrm{Al}(\mathrm{OH})_{3}[10]$. This corresponds to the fact that basic aluminum sulphate (and aluminum sulphate) has a greater inhibiting effect compared to $\mathrm{Al}(\mathrm{OH})_{3}$.

As have been said above, the use of aluminum-bearing salts results in very quick set of cement paste. If required, this problem may be resolved by introducing iron(II) sulphate, for example, $\mathrm{FeSO}_{4} \cdot 7 \mathrm{H}_{2} \mathrm{O}$, into cement paste along with aluminum-bearing substances. For example, in case of the composition with $\mathrm{Al}_{2} \mathrm{SO}_{4} \cdot 18 \mathrm{H}_{2} \mathrm{O}(1$ $\mathrm{wt} \%$ in terms of $\mathrm{Al}_{2} \mathrm{O}_{3}$ ) the initial set takes place in less than $5 \mathrm{~min}$. When the half of this amount was substituted by molar-equivalent dosage of $\mathrm{FeSO}_{4} \cdot 7 \mathrm{H}_{2} \mathrm{O}$ (in terms of $\mathrm{Fe}_{2} \mathrm{O}_{3}$ ) the initial set time has extended for the period of $50 \mathrm{~min}$ (chemically pure ferrous sulphate heptahydrate was previously dissolved in mixing water together with $\mathrm{Al}_{2} \mathrm{SO}_{4} \cdot 18 \mathrm{H}_{2} \mathrm{O}$ ). Meanwhile, as can be seen from Figure 1(b), the partial substitution of $\mathrm{Al}_{2} \mathrm{SO}_{4} \cdot 18 \mathrm{H}_{2} \mathrm{O}$ by $\mathrm{FeSO}_{4} \cdot 7 \mathrm{H}_{2} \mathrm{O}$ has no influence on the results of ASR expansion test. Apparently, ferrous sulphate takes part in formation of Fe-substituted ettringite ( $\mathrm{Al}$, Fe-ettringite, or AFt-phase) with binding of detrimental $\mathrm{Ca}(\mathrm{OH})_{2}$ but this process is more moderate than in case of single $\mathrm{Al}_{2} \mathrm{SO}_{4} \cdot 18 \mathrm{H}_{2} \mathrm{O}$.

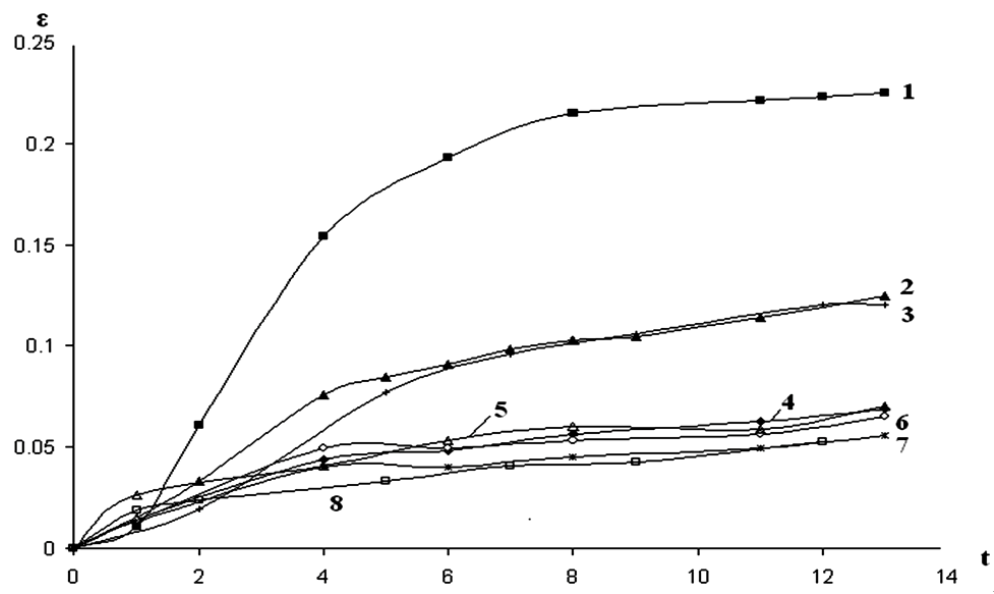

Figure 2. Linear expansion $\varepsilon(\%)$ of samples with aluminum-bearing and plasticizing admixtures $\left(1-\right.$ reference sample, 2, 3- $\mathrm{Al}(\mathrm{OH})_{3}$ without and with $\mathrm{C}-3$ plasticizer; $4,5,6,7,8-\mathrm{Al}_{2}\left(\mathrm{SO}_{4}\right)_{3}$ without plasticizing agent and with C-3, Melflux 2651F, Melment M10, LST plasticizers, respectively. Aluminum-bearing admixtures content is $1 \%$ (in terms of $\mathrm{Al}_{2} \mathrm{O}_{3}$ ) on the weight of PC; an amount of plasticizing agents is $0.1 \%$ of PC. 
As aluminum-bearing compounds affect the rheological properties of Portland cement compositions and are used in many cases together with plasticizing admixtures, it can be appropriate to examine the influence of the latter on the inhibitory effect of aluminum-bearing substances. Figure 2 shows the dependence of linear expansion with time for the samples with aluminum sulphate and aluminum hydroxide in the presence of four types of plasticizers: naphthalene-formaldehyde (C-3), melamine-formaldehyde (Melment M10), polycarboxylate (Melflux 2651F) and lignosulphonate (LST). As can be seen from the data presented in Figure 2, plasticizing agents do not affect the ability of aluminum-bearing admixtures to inhibit alkaline expansion.

\section{Conclusions}

1) Aluminum-bearing substances-amorphous aluminum hydroxide, aluminum sulphate and basic aluminum sulphate-mitigate alkali-silica reactions in Portland cement mortars with reactive $\mathrm{SiO}_{2}$-inclusions.

2) At equivalent dosages in terms of $\mathrm{Al}_{2} \mathrm{O}_{3}$, these substances are ranged in the following order in respect of inhibiting effect: $\mathrm{Al}(\mathrm{OH})_{1.78}\left(\mathrm{SO}_{4}\right)_{0.61} \geq \mathrm{Al}_{2}\left(\mathrm{SO}_{4}\right)_{3}>\mathrm{Al}(\mathrm{OH})_{3}$.

3) The plasticizing agents of the main types used in cement compositions have no influence on the inhibiting effect of aluminum-bearing admixtures.

4) To control the setting time of cement paste, iron(II) sulphate may be used for partial substitution of $\mathrm{Al}_{2} \mathrm{SO}_{4} \cdot 18 \mathrm{H}_{2} \mathrm{O}$, and this operation is not influenced on the results of ASR expansion test.

\section{References}

[1] Thomas, M.D.A. and Folliard, K.J. (2007) Concrete Aggregates and the Durability of Cocncrete. In: Page, C. and Page, M., Eds., Durability of Concrete and Cement Composites, CRC Press, New York.

[2] Siddique, R. and Khan, M.I. (2011) Supplementary Cementing Materials. Springer, Berlin. http://dx.doi.org/10.1007/978-3-642-17866-5

[3] Thomas, M. (2011) The Effect of Supplementary Cementing Materials on Alkali-Silica Reaction: A Review. Cement and Concrete Research, 41, 1224-1231. http://dx.doi.org/10.1016/j.cemconres.2010.11.003

[4] Feng, X., Thomas, M., Bremner, T., et al. (2005) Studies on Lithium Salts to Mitigate ASR-Induced Expansion in New Concrete: A Critical Review. Cement and Concrete Research, 35, 1789-1796. http://dx.doi.org/10.1016/j.cemconres.2004.10.013

[5] Thomas, M., Fournier, B., Folliard, K., et al. (2007) The Use of Lithium to Prevent or Mitigate Alkali Silica Reaction in Concrete Pavements and Structure. FHWA-HRT-06-133, US Dept. of Transportation, Federal Highway Administration, Washington.

[6] Natesaiyer, K. and Hover, K. (1992) Chemical Agents for Reducing Solubility of Silica in 1N Sodium Hydroxide. Cement and Concrete Research, 22, 653-662. http://dx.doi.org/10.1016/0008-8846(92)90017-P

[7] Brykov, A. and Anisimova, A. (2013) Efficacy of Aluminum Hydroxides as Inhibitors of Alkali-Silica Reactions. Materials Sciences and Applications, 4, 1-6. http://dx.doi.org/10.4236/msa.2013.412A001

[8] Myrdal, R. (2007) Accelerating Admixtures for Concrete. State of the Art: SINTEF report N SBF BK A07025, Trondheim.

[9] Sommer, M., Mader, U., Wombacher, F. and Lindlar, B. (2010) Solidification and Hardening Accelerator for Hydraulic Binding Agents and Method for the Production Thereof. Pat. 7699931, USA, pub. 20.04.

[10] Brykov, A., Vasilev, A. and Mokeev, M. (2013) Hydration of Portland Cement in the Presence of Aluminum-Containing Setting Accelerators. Russian Journal of Applied Chemistry, 86, 793-801.

[11] Ichikawa, T. and Miura, M. (2007) Modified Model of Alkali-Silica Reaction. Cement and Concrete Research, 37, 1291-1297. http://dx.doi.org/10.1016/j.cemconres.2007.06.008

[12] Chatterji, S. and Thaulow, N. (2000) Some Fundamental Aspects of Alkali-Silica Reaction. Proc. of the 11th International Conference on Alkali-Aggregate Reaction, Quebec, Qanada, 21-29. 